\title{
Aphids and ladybird beetle's abundance and diversity in alfalfa fields of Yasouj, southwestern of Iran
}

\author{
S. Mirfakhraie, ${ }^{1}$ K. Saeidi ${ }^{2}$ \\ ${ }^{1}$ Plant Protection Department, Faculty of Agriculture, Urmia University, Urmia; ${ }^{2}$ Plant Protection Research Department, \\ Fars Agricultural and Natural Resources Research and Education Center, AREEO, Shiraz, Iran
}

\begin{abstract}
Alfalfa (Medicago sativa L.) is the oldest and the most important forage legume. It has been cultivated for forage longer than any other crop. Diversity indices provide information about community composition. Diversity indices are measured by species richness and species evenness therefore, it could give us more ecological information rather than a simple species list in the fields. During 2015-2016, aphids and ladybird beetle's abundance and diversity were monitored in alfalfa fields of Yasouj. Samplings were conducted with 150 plants in the alfalfa fields from mid-May to mid-November. Species richness was measured using Shannon and Simpson indices. In this study, six aphids and five coccinellid species were collected and identified. Among the collected aphid species, Aphis fabae (Scopoli, 1763) and Therioaphis maculata (Buckton, 1899) were most abundant in the fields. For coccinellids, Coccinella septempunctata L. was the most abundant species. Highest aphid species diversity was observed on 17 May 2016.
\end{abstract}

Correspondence: Karim Saeidi, Plant Protection Research Department, Fars Agricultural and Natural Resources Research and Education Center, AREEO, Shiraz, Iran.

Tel.: +98.71.32622431 - Fax: +98.71.32623470.

E-mail: saeidi391@yahoo.com

Key words: Aphids, Coccinellidae, diversity, population, Yasouj, alfalfa.

Conflict of interest: the author declares no potential conflict of interest.

Received for publication: 29 May 2017.

Accepted for publication: 24 June 2017.

(C) Copyright S. Mirfakhraie and K. Saeidi, 2017

Licensee PAGEPress, Italy

Journal of Entomological and Acarological Research 2017; 49:6824

doi:10.4081/jear.2017.6824

This article is distributed under the terms of the Creative Commons Attribution Noncommercial License (by-nc 4.0) which permits any noncommercial use, distribution, and reproduction in any medium, provided the original author(s) and source are credited.

\section{Introduction}

Alfalfa (Medicago sativa L.) is a perennial plant that is native to Southwest Asia. Not only does alfalfa have very high yield potential, but it is also one of the most palatable and nutritious forage crops. Because of its high protein and vitamin content, alfalfa is a primary component in the diet of dairy cattle as well as beef cattle and horses (Summers, 1998). Currently 450-500,000 hectare of alfalfa are cultivated in Iran, of which about 2 thousand hectares are located in Kohgiluyeh va Boyerahmad province (Anonymous, 2014).

Alfalfa supports a diverse arthropod fauna; some species are pests but many have no effect on the crop (Alsuhaibani, 1996). At least 1000 species have been reported from alfalfa in the US, with perhaps 100-150 of these causing some degree of injury. Few of these, however, can be described as key pest species, the rest are only of local or sporadic importance, or are incidental herbivores, entomophagous (parasites and predators), or pollinators (Flanders \& Radcliffe, 2013). Alfalfa fields, as a short-term perennial agroecosystem, also support a wide range of arthropods, most of which have neither positive nor negative effects on the crop. In fact, alfalfa fields are important contributors to the biodiversity of agricultural systems (Putnam et al., 2001). The contribution of alfalfa to biological diversity and for the nurturing of beneficial insects for other species often goes unrecognized. This should be considered an important environmental benefit of incorporating alfalfa into a cropping system.

The aphids that attack the alfalfa are well-known in Iran and some other countries (Neuenschwander et al., 1975; Harper, 1978; Aeschlimann, 1981; Monajemi \& Esmaili, 1981; Takahashi \& Naito, 1984; Rasoulian, 1985). The Therioaphis trifolii (Monell), Acyrthosiphon pisum (Harris) and A. kondoi (Shinji) have been recorded as the major pests of alfalfa in Australia (Grimm, 1972) and New Zealand (Rohitha et al., 1985). The Aphis craccivora (Koch), A. pisum and T. trifolii were the aphid species recorded each year in Spain (Pons \& Lioveras, 1999; Pons et al., 2009). Two aphids, $A$. pisum and $A$. kondoi, were recorded as the most abundant alfalfa aphids in Japan (Takahashi \& Naito, 1984). Grigorov (1982) noted that the main aphids of alfalfa in Bulgaria were A. pisum and T. trifolii. Rasoulian (1985) and Monajemi \& Esmaili (1981) recorded A. pisum, A. kondoi, A. craccivora and $T$. trifolii as major pests of alfalfa in Karaj, Iran. Several species of aphids have been reported in Iran. Aphis fabae and Therioaphis maculata are the most abundant species in the alfalfa fields (Afshari \& Dastranj, 2010; Kamangar \& Malkeshi, 2010).

Alfalfa aphid natural enemies have been studied by some other 
research workers (Wheeler, 1974, 1977, 1978; Neuenschwander et al., 1975; Summers, 1976; Harper, 1978; Aeschlimann, 1981; Monajemi \& Esmaili, 1981; Takahashi \& Naito, 1984; Rasoulian, 1985; Nakashima \& Akashi, 2005; Rakhshani et al., 2006). Abdulmadzhid (1973) recorded 11 species of Coccinellidae, six species of Syrphidae, four species of Chrysopidae and one species of Nabidae and Aphidiinae that attack alfalfa aphids in Bulgaria. Takahashi \& Naito (1984) recorded Coccinella septempunctata L., Harmonia axyridis (Pallas) and Propylea japonica (Thunberg) as the main coccinellid predators of alfalfa aphids in Japan. Coccinella transversoguttata richardsoni Brown, Hippodamia parenthesis (Say), H. quinquesignata (Kby), H. tredecimpunctata tibialis (Say), H. sinuate disjuncta Timb (Col.: Coccinellidae), Scavea pyrastri (L.) (Dip.: Syrphidae), Nabis alternatus Parshley (Hem.: Nabidae), Orius tristicolor (White) (Hem.: Anthocoridae), Aeolothrips fasciatus (L.) (Thys.: Aeolothripidae) and Chrysopa oculata Say were recorded as important predators of alfalfa aphids in Canada (Harper, 1978). Monajemi \& Esmaili (1981) and Rasoulian (1985) recorded 18 and 19 species of alfalfa aphid natural enemies, respectively in Karaj, Iran. Aeschlimann (1981) found seven primary and 12 secondary parasites associated with alfalfa aphids in the Mediterranean region. Rakhshani et al. (2006) recorded 11 aphid parasitoid species in alfalfa fields in different parts of Iran.

The simplest way to measure species biodiversity is to count the number of species present in a designated area (Okpiliya, 2012). Kamangar \& Malkeshi (2010) reported the species and abundance of alfalfa aphids and coccinellids in Kurdistan province. There were 7 aphids and 6 coccinellid species in the fields. The most abundant aphid and ladybird species were Acyrhosiphon pisum (66.5\%) and Aphis craccivora (30\%), Hippodamia variegata Goeze $(60 \%)$ and C. septempunctata (37\%). Diversity indices provide information about community composition. Diversity indices are measured by species richness (the total number of species present) and species evenness (the distribution of the individuals within species designations); therefore, it could give us more ecological information rather than a simple species list in the fields (Okpiliya, 2012). Although there are numerous studies on the diversity of alfalfa aphids in Iran, no studies have been conducted in the alfalfa fields of Yasouj. Yasouj has fewer limitations for alfalfa production and also it can be suggested as rainfed cultivation because of its low stress. Therefore, Yasouj has the high level of rainfed alfalfa production in Iran (Afshari \& Dastranj 2010).

The aim of this study was to investigate the abundance and species diversity of alfalfa aphids and their predatory ladybirds using the Shannon's (H) and Simpson's Indices of diversity at various time intervals throughout two years in Yasouj-Kohgiluyeh va Boyerahmad.

\section{Material sand methods}

\section{Collecting alfalfa aphids}

In order to collect alfalfa aphids, sampling was conducted every two weeks during the growing season of 2015 and 2016 in three half-hectare fields of alfalfa, Medicago sativa (Var. Hamedani) located in Yasouj city. The sampling alfalfa fields were in Chamkhani station (51 35'21'N 57²5'21'”E), Mazdak $\left(51^{\circ} 366^{\prime} 22^{\prime \prime N} 51^{\circ} 37^{\prime} 23\right.$ 'E) and Amirabad village $\left(51^{\circ} 26^{\prime} 33^{\prime \prime} \mathrm{N}\right.$ $52^{\circ} 38^{\prime} 4^{\prime \prime}$ ). Alfalfa was planted in November (both 2014 and 2015 year) and sampling was conducted from mid- May until midNovember in flowering stage. Sampling was performed from a corner of the field and continued throughout the field in a $Z$ pattern. On each sampling date, six 20-sweep samples were taken using a $38 \mathrm{~cm}$ diameter sweep-net and also six 20-stem were sampled. Samples were labelled, placed in plastic bags and transported to the laboratory for separating and counting. Each bag was labeled with the information of the sampling date and location. In the laboratory, a cottonpad was soaked in chloroform and placed in each plastic bag for 5 min until the insects died. Subsequently, aphids were identified and their number was counted.

\section{Collecting alfalfa coccinellids}

The ladybirds were collected using standard nets and in some cases ladybirds were collected straight from the alfalfa crops by hand. Samples of adult ladybirds were kept in $70 \%$ ethanol (alcohol) to be used for the separation and preparation of their genitalia for microscope slides. For the preparation of the microscopic slides, the ladybirds' abdomens (from larger specimens) were separated from other parts of the body and placed in cold $10 \%$ potassium hydroxide solution for 24 hours, meanwhile the smaller ladybird specimens were placed whole into a solution of potassium hydroxide (Afshari \& Dastranj, 2010). This procedure was used to decolorize the genital organs in order for them to appear clear on the microscope slide. In the next step, the sections of insects necessary for observation were put in to alcohol with various proportions until the texture showed a state of dehydration and air bubbles were observed on the surface of the samples. Then the male genitalia that include the sipho and tegmen were separated using two dissecting needles and then placed on a slide. For the determination of species, the Coccinellidae (Coleoptera) of America North of Mexico (Gordon, 1985) identification key was used. A number of ladybird species could not be identified using this key and were sent to Dr. Fursch from Germany for identification.

\section{Equations}

The Shannon-Wiener's (eq. 1) (Magurran, 1988) and Simpson's (eq. 2) (Simpson, 1949) diversity indices were used to calculate the diversity. The Pielou's (eq. 3) (Price, 1997) and Simpson's (eq. 4) indices were used to calculate evenness of aphids and coccinellids communities.

Equation 1: Shanon's diversity indices:

$$
H^{\prime}=-\sum_{i=1}^{N_{\mathrm{o}}}[p i \log p i]
$$

where, $p i$ is the proportion of $i$ th species among all collected samples, and $s$ is the total number of species in the community.

Equation 2: Simpson's diversity indices:

$$
1-\mathrm{D}=1-\sum_{i=1}^{N} \frac{n i(n i-1)}{N(N-1)}
$$

where, 1-D: Simpson's index, ni: number of individuals in ith species, N: total number of individuals in all collected species. Equation 3: Pielou's evenness:

$$
\mathrm{J}=\frac{H^{\prime}}{\ln (S)}
$$

where, $s$ is the total number of species in the community (richness) and $H^{\prime}$ is Shannon's diversity index.

Equation 4: Simpson's equitability (evenness):

$$
\mathrm{ED}=\underset{\operatorname{Dmax}}{\mathrm{D}}=\sum_{i=1}^{s} \frac{1}{p i^{2}} \times \frac{1}{s}-
$$




\section{Results}

Six species of alfalfa aphids belonging to Aphididae family were identified including Aphis fabae (Scopoli, 1763), Therioaphis maculate (Buckton, 1899), Acyrhosiphon pisum (Harris, 1776), Aphis craccivora (C.L. Koch, 1854)., Therioaphis trifolii (Monell, 1882) and Therioaphis pisum Fitch. Also, five species of coccinellids were identified including Coccinella septempunctata, Hippodamia variegata Goeze, Exochomus nigromaculatus Goeze, Hippodamia tredecimpunctata L. and Adalia bipunctata L. Table 1 and 2 show the number and the frequency of occurrence of aphid species in 2015 and 2016, respectively. Aphis fabae and Therioaphis maculata were the most abundant aphid species in the fields.

The highest Shanon's $\left(H^{\prime}\right)$ diversity index of aphids was obtained on 22 May (1.543) followed by 6 August (1.352) with equitability indices of 0.310 and 0.238 , respectively (Table 3 ). The highest Simpson's index (0.773) was also calculated on 22 May (Table $3)$. In 2015, the highest Shannon's index of aphids was calculated on 17 May (1.595) followed by 2 July (1.320); however, for Simpson's index, the highest aphid's diversity index was reported on 17 May (Table 4). Generally, diversity indices of aphids in 2015 were higher than in 2016. Coccinella septempunctata was more abundant compared to the other species (Table 5). Diversity indices of ladybirds were higher in 2016 than 2015 (Table 6). Simpson's diversity index of ladybirds in 2015 and 2016 were 0.68 and 0.72 , respectively indicating that the possibility of selecting two different species of coccinellids is $68 \%$ in 2015 and $72 \%$ for 2016 .

\section{Discussion and Conclusions}

In this study six aphid and five coccinellid species were iden- tified. Aphid numbers increased throughout the season from 145 aphids on 22 May 2015 to a maximum of 846 aphids on 6 July 2015 after time which they began to decline again.

On 22 October 2015, only three A. fabae, A. craccivora and T. maculata species were observed in the region and their population ceased and reached the zero on 6 November. A similar trend was observed in 2016. expressed biotic factors such as low temperature and continuous snow can also reduce aphid's populations.

Alfalfa fields are sprayed by pesticides in urgent cases only when Alfalfa weevil (Hypera postica Gylln.) populations get above the economic level. In Iran, the main infestation areas of Alfalfa weevil are in the provinces of Hamedan, Fars, Kohgiluyeh va Boyerahmad, Kermanshah, Kurdistan, West Azerbaijan, Tehran, Ardabil and East Azerbaijan (Afshari \& Dastranj, 2010). Our findings indicated that there was a large population of C. septempunctata in the fields. It seems the presence of high ladybird species in the Alfalfa fields is because the fields are not sprayed by pesticides. However, the results showed that at the end of the sampling period in both years ladybird populations decreased significantly. The population decline coincided with ripening Alfalfa suggesting migration of coccinellids to other shelters, especially for summer aestivation. Grez et al. (2013) stated that coccinellids were more abundant when surrounding landscapes had more native shrublands and semi-urban areas than in those with more annual crops. Therefore, the presence of regular patches around the fields and landscape composition and heterogeneity affects not only the composition of coccinellids but also the efficacy of these biological control agents.

Zhao et al. (2013) stated that abundance, species richness and diversity increased with increasing plant diversity and landscape complexity. In our study, small and simple structure of the landscapes were examined that expected to decrease the richness of the aphids and ladybirds. Diversity indices depend not only on species

Table 1. Frequency of occurrence of aphid species at different time intervals in alfalfa fields of Yasouj in 2015.

\begin{tabular}{|c|c|c|c|c|c|c|c|c|c|c|c|c|c|c|c|}
\hline Species & $\begin{array}{c}22 \\
\text { May }\end{array}$ & $\begin{array}{c}5 \\
\text { June }\end{array}$ & $\begin{array}{c}22 \\
\text { June }\end{array}$ & $\begin{array}{c}6 \\
\text { July }\end{array}$ & $\begin{array}{c}23 \\
\text { July }\end{array}$ & $\begin{array}{c}6 \\
\text { Aug }\end{array}$ & $\begin{array}{c}23 \\
\text { Aug }\end{array}$ & $\begin{array}{c}6 \\
\text { Sept }\end{array}$ & $\begin{array}{l}23 \\
\text { Sept }\end{array}$ & $\begin{array}{c}7 \\
\text { Oct }\end{array}$ & $\begin{array}{l}22 \\
\text { Oct }\end{array}$ & $\begin{array}{c}6 \\
\text { Nov }\end{array}$ & $\begin{array}{c}21 \\
\text { Nov }\end{array}$ & No & $\begin{array}{l}\text { Relative } \\
\text { requency }\end{array}$ \\
\hline A. fabae & 50 & 146 & 268 & 368 & 256 & 106 & 75 & 56 & 43 & 20 & 10 & 0 & 0 & 1398 & 40.05 \\
\hline A. craccivora & 30 & 48 & 73 & 178 & 128 & 89 & 56 & 32 & 21 & 11 & 7 & 0 & 0 & 673 & 19.29 \\
\hline T. maculata & 24 & 200 & 388 & 238 & 86 & 75 & 53 & 39 & 28 & 21 & 13 & 0 & 0 & 1165 & 33.39 \\
\hline A. pisum & 0 & 0 & 0 & 33 & 18 & 7 & 4 & 0 & 0 & 0 & 0 & 0 & 0 & 62 & 1.78 \\
\hline T. trifolii & 18 & 13 & 26 & 21 & 15 & 12 & 6 & 3 & 1 & 1 & 0 & 0 & 0 & 116 & 3.32 \\
\hline T. pisum & 23 & 16 & 12 & 8 & 6 & 4 & 3 & 2 & 1 & 1 & 0 & 0 & 0 & 76 & 2.17 \\
\hline Total & 145 & 423 & 767 & 846 & 509 & 293 & 197 & 132 & 94 & 54 & 30 & 0 & 0 & 3490 & 100 \\
\hline
\end{tabular}

Table 2. Frequency of occurrence of aphid species at different time intervals in alfalfa fields of Yasouj in 2016.

\begin{tabular}{|c|c|c|c|c|c|c|c|c|c|c|c|c|c|c|c|}
\hline Species & $\begin{array}{c}17 \\
\text { May }\end{array}$ & $\begin{array}{c}1 \\
\text { June }\end{array}$ & $\begin{array}{c}16 \\
\text { June }\end{array}$ & $\begin{array}{c}2 \\
\text { July }\end{array}$ & $\begin{array}{c}20 \\
\text { July }\end{array}$ & $\begin{array}{c}5 \\
\text { Aug }\end{array}$ & $\begin{array}{c}20 \\
\text { Aug }\end{array}$ & $\begin{array}{c}4 \\
\text { Sept }\end{array}$ & $\begin{array}{c}19 \\
\text { Sept }\end{array}$ & $\begin{array}{c}3 \\
\text { Oct }\end{array}$ & $\begin{array}{l}18 \\
\text { Oct }\end{array}$ & $\begin{array}{c}3 \\
\text { Nov }\end{array}$ & $\begin{array}{c}18 \\
\text { Nov }\end{array}$ & No & $\begin{array}{l}\text { Relative } \\
\text { frequency }\end{array}$ \\
\hline A. fabae & 35 & 110 & 178 & 253 & 210 & 98 & 82 & 45 & 41 & 16 & 8 & 0 & 0 & 1076 & 38.88 \\
\hline A. craccivora & 34 & 52 & 65 & 145 & 118 & 78 & 51 & 24 & 16 & 10 & 4 & 0 & 0 & 597 & 21.57 \\
\hline T. maculata & 30 & 165 & 234 & 187 & 72 & 61 & 42 & 32 & 19 & 11 & 9 & 5 & 0 & 867 & 31.34 \\
\hline A. pisum & 0 & 3 & 1 & 22 & 15 & 6 & 3 & 1 & 1 & 0 & 0 & 0 & 0 & 52 & 1.88 \\
\hline T. trifolii & 23 & 18 & 21 & 17 & 12 & 9 & 3 & 2 & 1 & 1 & 0 & 0 & 0 & 107 & 3.87 \\
\hline T. pisum & 31 & 12 & 8 & 6 & 4 & 2 & 2 & 1 & 1 & 1 & 0 & 0 & 0 & 68 & 2.46 \\
\hline Total & 153 & 360 & 507 & 630 & 431 & 254 & 183 & 105 & 79 & 39 & 21 & 5 & 0 & 2767 & 100 \\
\hline
\end{tabular}


richness but also on the evenness, or equitability, with which individuals are distributed among the different species (Okpiliya 2012). In our study, maximum and minimum value of Simpson's index for coccinellids community was 0.804 on 17 May 2016 and 0.599 on 22 June 2015. The Simpson's index of aphids in 2015 and 2016 were 0.0 .647 and 0.617 , respectively. This suggests that the possibility of selecting two different species of aphids randomly in the checked fields in 2015 was $64 \%$ while for the year 2016 the possibility was $61 \%$. For coccinellids, Simpson's index was 0.693 and 0.829 for 2015 and 2016, respectively. The low species diversity index (Simpson) could be due to the uniform distribution of individuals among species.

Because of resources limitations, only three fields were evaluated in this study. The given list shows only a part of the regional fauna and the preparation of a complete list of aphids and coccinel- lids in Kohgiluyeh va Boyerahmad province needs that the study by extended to a wider area.

\section{References}

ABDULMADZHID A.A., 1973 - Control of Acyrthosiphon pisum with natural enemies and insecticides - Rastitelna Zashchita 21: 39-41.

AESCHLIMANN J.P., 1981 - Occurrence and natural enemies of Therioaphis trifolii Monell and Acyrthosiphon pisum Harris (Homoptera, Aphididae) on lucerne in the Mediterranean region - Acta Oecol., Oecol. Appl. 2: 3-11.

AFSHARI A., DASTRANI M., 2010 - Density, spatial distribution

Table 3. Diversity indices of aphid's community at different time intervals in alfalfa fields of Yasouj in 2015.

\begin{tabular}{|c|c|c|c|c|c|c|c|c|c|c|c|c|}
\hline Diversity Indices & 22 May & 5 June & 22 June & 6 July & 23 July & 6 Aug & 23 Aug & $6 \mathrm{Sept}$ & 23 Sept & 7 0ct & 22 0ct & Total \\
\hline $\mathrm{H}$ & 1.543 & 1.193 & 1.115 & 1.305 & 1.263 & 1.352 & 1.323 & 1.231 & 1.147 & 1.204 & 1.066 & 13.742 \\
\hline EH & 0.310 & 0.197 & 0.167 & 0.193 & 0.202 & 0.238 & 0.250 & 0.252 & 0.252 & 0.301 & 0.313 & 2.675 \\
\hline 1-D & 0.773 & 0.636 & 0.599 & 0.684 & 0.645 & 0.713 & 0.696 & 0.677 & 0.657 & 0.681 & 0.668 & 7.429 \\
\hline ED & 0.605 & 0.466 & 0.429 & 0.514 & 0.475 & 0.543 & 0.526 & 0.507 & 0.487 & 0.511 & 0.498 & 5.561 \\
\hline
\end{tabular}

Table 4. Diversity indices of aphid's community at different time intervals in alfalfa fields of Yasouj in 2016.

\begin{tabular}{lccccccccccccc} 
Diversity Indices & 17 May & 1 June & 16 June & 2 July & 20 July & 5 Aug & 20 Aug & 4 Sept & 19 Sept & 3 Oct & 18 Oct & Total \\
H & 1.595 & 1.303 & 1.131 & 1.320 & 1.258 & 1.312 & 1.229 & 1.224 & 1.169 & 1.256 & 1.048 & 13.845 \\
EH & 0.318 & 0.221 & 0.181 & 0.204 & 0.207 & 0.237 & 0.236 & 0.263 & 0.267 & 0.343 & 0.344 & 2.821 \\
\hline 1-D & 0.804 & 0.674 & 0.645 & 0.697 & 0.659 & 0.699 & 0.671 & 0.676 & 0.639 & 0.762 & 0.667 & 7.593 \\
ED & 0.636 & 0.506 & 0.477 & 0.529 & 0.491 & 0.531 & 0.503 & 0.508 & 0.471 & 0.594 & 0.499 & 5.745 \\
\hline
\end{tabular}

Table 5. Frequency of occurrence and relative frequencies of ladybird's community in alfalfa fields of Yasouj during 2015 and 2016.

\begin{tabular}{|c|c|c|c|c|}
\hline \multirow[t]{2}{*}{ Species } & \multicolumn{2}{|c|}{2015} & \multicolumn{2}{|c|}{2016} \\
\hline & No & Relative frequency (\%) & No & Relative frequency (\%) \\
\hline Coccinella septempunctata L. & 268 & 49.08 & 234 & 50 \\
\hline Hippodamia. variegata Goeze & 123 & 22.52 & 106 & 22.65 \\
\hline Exochomus nigromaculatus Goeze & 69 & 12.63 & 57 & 12.18 \\
\hline Hippodamia tredecimpunctata $\mathrm{L}$. & 51 & 9.35 & 42 & 8.98 \\
\hline Adalia bipunctata $\mathrm{L}$. & 35 & 6.42 & 29 & 6.19 \\
\hline Total & 546 & 100 & 468 & 100 \\
\hline
\end{tabular}

Table 6. Dversity indices of ladybird's community at different time intervals in alfalfa fields of Yasouj during 2015 and 2016.

\begin{tabular}{lll} 
& 2015 & 2016 \\
H & 1.339 & 0.976 \\
EH & 0.985 & 0.762 \\
\hline I-D & 0.693 & 0.829 \\
ED & 0.108 & 0.115 \\
\hline
\end{tabular}

H: Shannon's Index, EH: Shannon's equitability, 1-D: Simpson's index, ED: Simpson's equitability. 
and sequential sampling plans for cereal aphids infesting wheat spike in Gorgan, northern Iran - Plant Protect. (Sci. J. Agricult.) 32: 89-102.

ALSUHAIBANI A.M., 1996 - Entomofauna of Alfalfa in Riyadh, Saudi Arabia - J. King Saud. Univ. Agric. Sci., 8: 269-277.

ANONYMOUS, 2014 - Agronomy information bank (2012-2013), The Ministry of Jihad-e- Agriculture, Iran - Available on: http://www.agri-jahad.org (accessed 10 February 2014).

FLANDERS K.L., RADCLIFFE E.B., 2013 - Alfalfa IPM - In: RADCLIFFE E.B., HUTCHISON W.D., CANCELADO R.E., (eds.). Radcliffe's IPM World Textbook, University of Minnesota, St. Paul, MN. Available form: http://ipmworld. umn.edu. Accessed: February, 2016.

GORDON R.D., 1985 - The Coccinellidae (Coleoptera) of America North of Mexico - J. New York Entomol. Soc. 93: 1985

GREZ A.A., ZAVIEZO T, RODRIGUEZ-SAN PEDRO A., HERNANDEZ J., ACUNA P., 2013 - Effects of landscape composition and heterogeneity on the abundance of native coccinelids and biological control of aphids in alfalfa fields. In: International Symposium Ecology of Aphidophaga, Belgrade Serbia: p.13.

GRIGOROV S. 1982 - Interrelations between cereal aphids and their natural enemies on Lucerne - Rasteniev dni-Nauki 19: 94-105.

GRIMM M., 1972 - Learning to live with the spotted alfalfa aphid - J. Agricult. West. Austral. 20: 82-84.

HARPER A.M., 1978 - Effect of insecticides on the pea aphid, Acyrthosiphon pisum (Hemiptera: Aphididae), and associated fauna on alfalfa - Canad. Entomol. 110: 891-894.

KAMANGAR S., MALKESHI S.H., 2010 - Fauna of cereal aphids and their coccinellid predators and investigation on the efficiency and population dynamics of the dominant species in Kurdistan province - J. Entomol. Res. 2: 279-293.

KOCH R.L., 2003 - The multicolored Asian lady beetle, Harmonia axyridis: a review of its biology, uses in biological control, and non-target impacts - J. Insect Sci. 3: 32.

MAGURRAN A.E., 1988 - Ecological diversity and its measurement - Princeton University Press.

MONAJEMI H., ESMAILI M., 1981 - Population dynamics of lucerne aphids and their natural controlling factors in Karaj. J. Entomol. Soc. Iran 6: 41-63.

NAKASHIMA Y., AKASHI M., 2005 - Temporal and within-plant distribution of the parasitoid and predator complexes associated with Acyrthosiphon pisum and A. kondoi (Homoptera: Aphididae) on alfalfa in Japan - J. Appl. Entomol. Zool. 40: 137-144.

NEUENSCHWANDER P., HAGEN K.S., SMITH R.F., 1975 Predation on aphids in California's alfalfa fields - Hilgardia 43: 53-78.

OKPILIYA F., 2012 - Ecological diversity indices: any hope for one again? - J. Environ. Earth Sci. 2: 45-52.
PONS X., LIOVERAS J., 1999 - Aphid population densities on alfalfa cultivars in the irrigated area of Lleida - Investig. Agrar. Prod. Protec. Vegetal. 14: 405-413.

PONS X., LUMBIERRES B., ALBAJES R., 2009 - Heteropterans as aphid predators in inter-mountain alfalfa - Eur. J. Entomol. 106: 369-378.

PRICE P.W., 1997 - Insect ecology. 3rd ed. - John Wiley \& Sons, New York.

PUTNAM D.H., SUMMERS C.G., ORLOFF S.B., 2001 - Alfalfa production systems in California, University of California, Agricultural and Natural Resources Communication Services. Okland, California.

RAKHSHANI E., TALEBI A.A., MANZARI S., REZWANI A., RAKHSHANI H., 2006 - An investigation on alfalfa aphids and their parasitoids in different parts of Iran, with a key to the parasitoids (Hemiptera: Aphididae; Hymenoptera: Braconidae: Aphidiinae) - J. Entomol. Soc. Iran 25: 1-14.

RAKHSHANI H., EBADI R., MOHAMMADI A.A., 2010 Population dynamics of alfalfa aphids and their natural enemies, Isfahan, Iran. - J. Agricult. Sci. Technol. 11: 505-520.

RASOULIAN G.R., 1985 - Investigation on the biology and population fluctuation of important alfalfa aphids in Karaj, Iran. $\mathrm{Ph}$. D. Thesis. College of Agriculture, University of Tehran.

ROHITHA B.H., POTTINGER R.P., FIRTH A.C., 1985 Population monitoring studies of lucerne aphids and their predators in the Waikato. Proceedings, New Zealand Weed and Pest Control Conference 38: 31-34.

SIMPSON E.H., 1949 - Measurement of diversity. - Nature 163: 688.

SUMMERS C.G., 1998 - Integrated pest management in forage alfalfa. Integr. Pest Manag. Rev. 3: 127-154.

TAKAHASHI K., NAITO A., 1984 - Seasonal occurrence of aphids and their predators (Col.: Coccinellidae) in alfalfa fields - Bull. Natl. Grassland Res. Inst. Japan 29: 62-66.

WHEELER A.G., 1974 - Studies on the arthropod fauna of alfalfa, plant bugs (Miridae) - Canad. Entomol. 106: 1267-1275.

WHEELER A.G., 1977 - Studies on the arthropod fauna of alfalfa, predaceous insects - Canad. Entomol. 109: 423-427.

WHEELER A.G., 1978 - Studies on the arthropod fauna of alfalfa, parasitoid-host records - Canad. Entomol. 110: 1117-1119.

XIMENEZ-EMBUN M.G., ZAVIEZO T., GREZ A., 2014 Seasonal, spatial and diel partitioning of Acyrthosiphon pisum (Hemiptera: Aphididae) predators and predation in alfalfa fields - Biol. Control. 69: 1-7.

ZHAO Z.H., LIU J.H., HE D.H., GUAN X.Q., LIU W.H., 2013 Specie composition and diversity of parasitoids and hyper-parasitoids in different wheat agro-farming systems - J. Insect Sci. 13: $1-8$. 